UDC 621.396. $67: 621.397 .6(058)$

\title{
5. テレビアンテナ
}

昭和 34 年度はわが国に括けるテレビジョンの発展史 上最も重要な時期であった。すなわちテレビチャネルの 12 チャネルへの変更, 電波塔による鉄塔共用, $50 \mathrm{~kW}$ への電力增加なぞが行われ, さらにテレビ数十局が新設 されるなど電気通信，放送界の話題はテレビに集中した 観がある。このためテレビ送受信アンテナについても幾 多の問題が生じ, 学界, 業界に掠いての報告が非常に多 い.これらを含み一，二年のテレビアンテナの動向の全 ぼうを述ることは困難なので，その 1,2 をこに述べ御 参考供したいと思う。

\section{テレビ送信アンテナ系}

わが国に括けるテレビ送信アンテナはスーパー・ター ンスタイルアンテナとスーパー・ゲーンアンテナの二種 であり，他の型のアンテナは実用されていない。この種 のアンテナは昭和 29 年以降実用されて, 特に技術的な 問題はなかったが, 本年に至り 1,2 の問題が生じた。

1. スーパー・ターンスタイルアンテナ

（1）チャネル共用アンテナ(1)

スーパー・ターンスタイルアンテナを二つのチャネル で共用する試みが NHK 東京で行われた. 第 1 抽よび第 3 チャネルが共用できるようにアンテナのバットウィン グの形を適当に選び，特殊の整合回路を插入して所望の 帯域で 1.05 以内の SWR を得た(第 1 図).

(2) 垂平面指向性 ${ }^{(2)}$

スーパー・ターンスタイルアンテナのポールの太さは 強度の関係から太くする傾向にあったが，ポールの太さ を著しく太くすると第 2 図のよ5に指向性が尖鋭になっ て，EW，NS 両面の合成指向性は著しく均一性をかき， $\pm 10 \mathrm{~dB}$ の Horizontal Cercularity (一般には $\pm 2 \sim 3 \mathrm{~dB}$ ) になることも岁る。これが対策としてはポールの太さを 太くせず，かつ電界の強い才向を都市にむけるようアン テナの位置をあらかじめ調整することが大切である．

(3) NS-EW 面間の結合による SWR 低下(3)(4)(5)

“TV Antenna”, by Risaburo Sato
東北大学 佐藤 利三 郎

NS 面，EW 面のバットウイングは，共に近接して存 在しているので, NS 面からの電波が $\mathrm{EW}$ 面のアンテナ に漏洩し，電源側にまわってきて，SWR を低下する現 象が発見された. その後各方面の調査によってバットウ イングと分岐線路を接続するジャンパーが，その結合の 主要な原因であることが明らかとなり，ジャンパーの小 型化，対称接続などによって 30〜 40dB の結合量に低下 することができた， RCA ではこの結合量を $36 \mathrm{~dB}$ 以上 に調整している．第 2 図にその一例を示す.

2. スーパー・ゲーンアンテナ

(1) スーパー・ゲーンアンテナの指向性の改善 ${ }^{(6)}$

スーパー・ダーンアンテナは，アンテナの大きさと反 射板の大ささが殆んど同じ程度であるため，無限大反射 板としての理論とは異った指向性をもつ傾向が女る. 一 個の場合の指向性の振幅特性と位相特性を実測して合成 すれば，実際に合致した指向性の得られることなどが明 らかとなった。一例を第 3 図に示す.

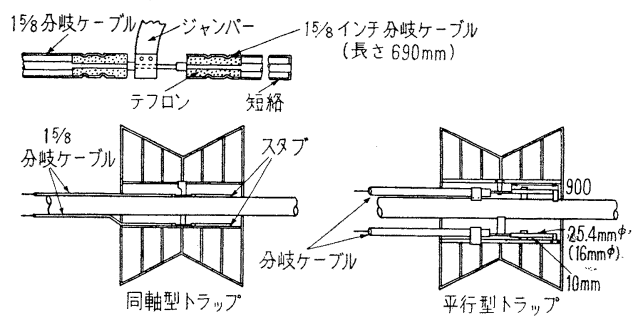

（a）リアクタンス禣償回路

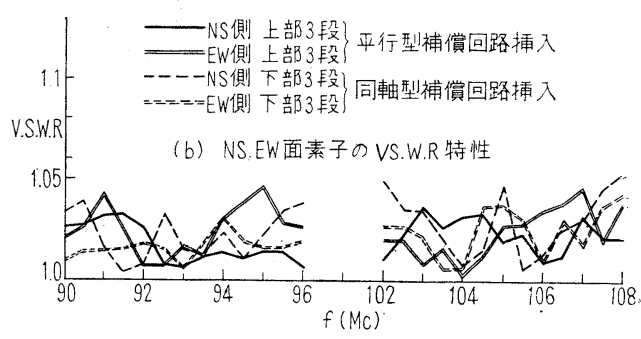

第1図 スーパー・ターンスタイルアンテナの 広帯域化

テレビジョン 


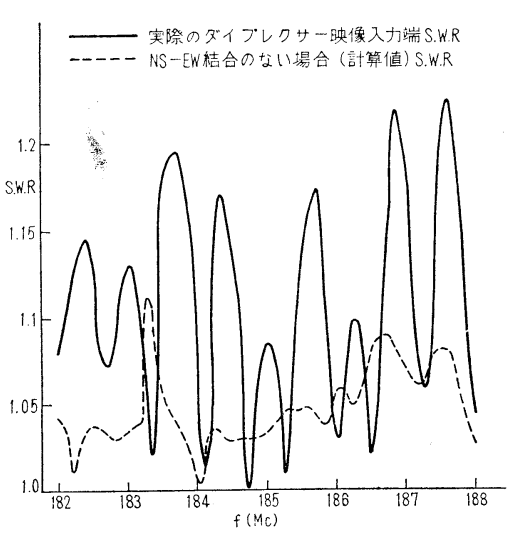

第 2 図 スーパー・ターンスタイルア ンテナのNS-EW 間結合によ るSWRの变化

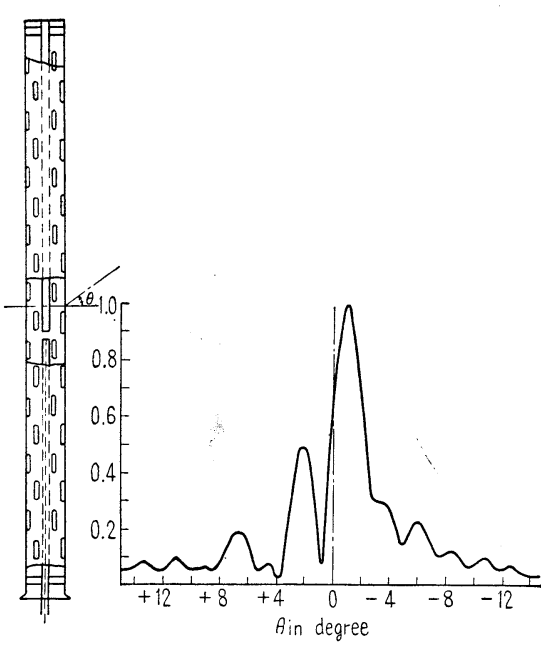

第 4 図 スロットアンテナ
（2）スーパーダーン・アンテナの SWR の広帯域化 スーパー・ゲーンアンテナはチャネルの周波数特性は 狭く第 1 チャンネルなどの低いチャネルで $6 \mathrm{Mc}$ を得る ことは非常に困難であった. これの解決が種々研究され たが，簡単な方法は支持トラップの特性インピーンダス を低下させるか，集中容量をアンテナに並列接続するか が考えられ，この方法によって 80〜90 Mc の帯域で 1.1 以内にとどめ得ることなどが明らかとなった。

(3) その他のアンテナ(8)(9)(10)(11)(12)

前述のアンテナはいずれも広く実用されてはいるが， 分岐線路の数が多く, High Band 用 UHF 帯用のよう

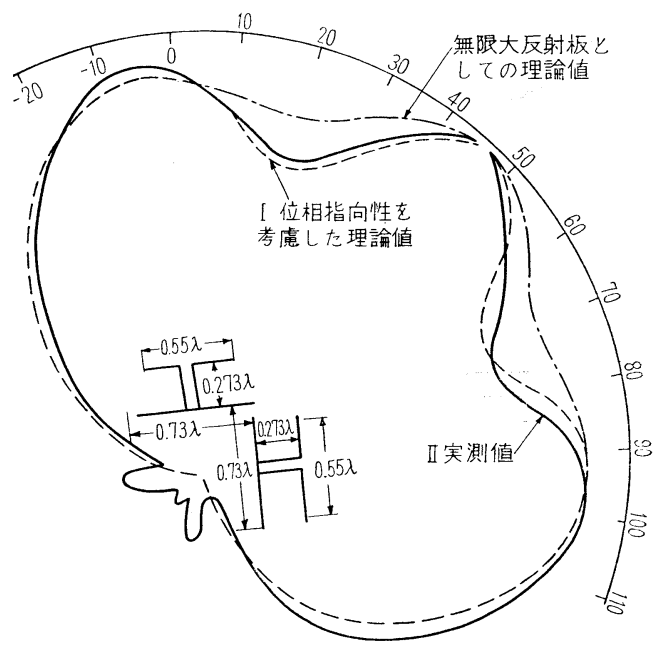

第3図 スーパー・ゲーンアンテナの位相特性に よる指向性の变化
に High gain のアンテナの要求に対し構造上無理があ. る. これに対しアメリカに括いては Slotted Antenna による Traveling Wave Antenna( ${ }^{(8)}$, および Slotted Ring Antenna(9), Helical Antenna(10)などが研究され. 実用されている。わが国に拈いても NHK その他で研. 究(11)されているし，またこれらの改良型なども一，二報。 告されている. 第 4，5，6図にはそれらアンテナの概要. 図を示した.

（4）テレビ送信伝送系

$50 \mathrm{~kW}$ 増力とアンテナ設置高の増加につれて, 伝送系: の耐厈, 温度上昇および伝送特性が種々問題になる.

伝送線路：伝送線路は $6 \mathrm{~m}$ 定尺の同軸管 $(50 \Omega)$ が用い. られ，新しい $47 / 4$ 吋管が製作され，電波塔のアンテナ給電: に用いられた。この同軸管の SWR 特性は第 7 図に示す. ように約 $24.5 \mathrm{Mc}$ 毎に反射波が加算されて悪化する ${ }^{(11)}$..
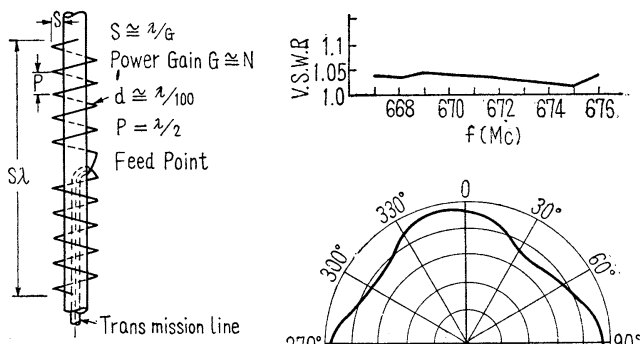

第 6 図ヘリカル アンテナ

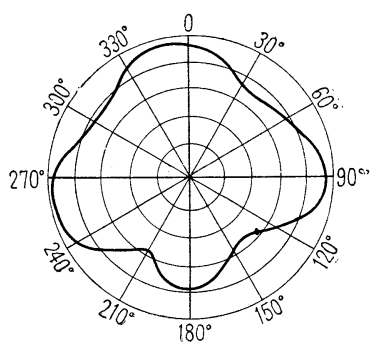



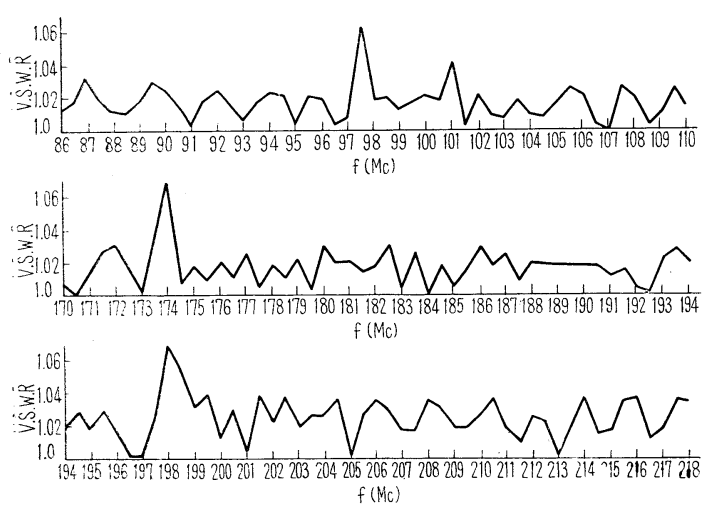

第 7 図 $300 \mathrm{~m}$ 同軸管の SWR

$2,4,8$ チャネル付近はこの悪化する周波数に当たるので $6 \mathrm{~m}$ 定尺を避けて使用されている. 耐圧, 温度上昇も試 験されたが現在のところ使用には十分である。またドイ ツの F \& G で製作されたスチロフレックスケーブル(12) （アルミ外被で 銅内部導体の同軸型線路）が各国で使用 されつつある。

伝送機器 ${ }^{(13)}$ : 伝送機器としては Harmonic Filter の 研究，ノッチダイプレクサー，ダイプレッサーなどの大 電力用の開発および VSBF の位相特性と画質の問題な ども研究されている.

\section{テレビ受信アンテナ系}

テレビ受信についてはチャネルの増加による広帯域な 受信アンテナの要求とテレビ画質向上のためのアンテナ 系改良の要求がなされた.

1. テレビ受信アンテナ

(1) テレビ受信アンテナの測定法

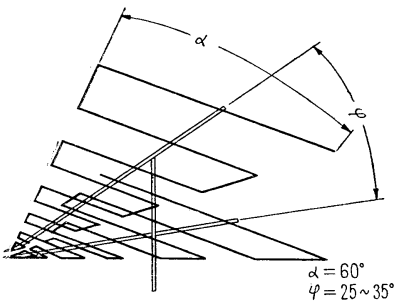

第 8 図対数周期ア ンテナ

(Freq independent Antenna)

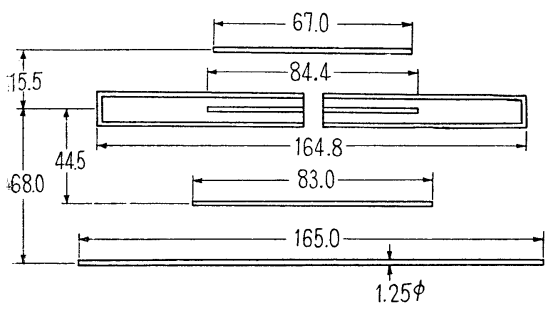

第 9 図二周波用広帯域アンテナ
テレビ受信アンテナは現在統一されない測定法で行わ れているため, 電力利得に拈いては相当違った值を示し ている.電波技術協会受信アンテナ委員会では, その仕事 の一つとして諸外国の例を調査し，わが国に合致した測 定法の立案に努力し近く公報されることになっている.

(2) 広帯域受信アンテナ(14)(15)(16)

対数周期型の広帯域アンテナの実用化がアメリカにお いて完成し，わが国に拈いても実用化研究がなされてい る.これは第 8 図に示す構造で $10 f_{0}$ まで殆んぞ一定で, 利得も 6 7 dB である. またX型空中線を二周波用に 共用するアンテナ ${ }^{(17)}$ (第 9 図) の研究もなされ，4 素子 八木空中線とした場合には低域 $3 \mathrm{~dB}$, 高域 $5 \mathrm{~dB}$ の電力 利得があり，VSWR は 3 以下で中電界用として十分な 特性をもつ.

また複合八木アンテナとして第 10 図のように構成し たアンテナも High, Low 両帯域に実用でき, VSWR は3 以下で, 投射器, 反射器を加えて中電界用にも実用 可能である.

Series Rhombic Antenna(18) は第 11 図のような形 状であり，使用周波数は $\pm 25 \%$ で SWR 2.5 以内電力 利得 $7 \mathrm{~dB}$ である.

Channel Master 社の進行波形全域空中線は, 低域(54 〜88 Mc) 高域 (173〜222 Mc) とをカバーする広带域 なもので,形状は第 12 図で投射器, 導波器は平行二本線 を折曲げた折返し空中線が使用される.投射器特よび導 波器は平行二線を通じて給電される. 電力利得低域 $3 \mathrm{~dB}$

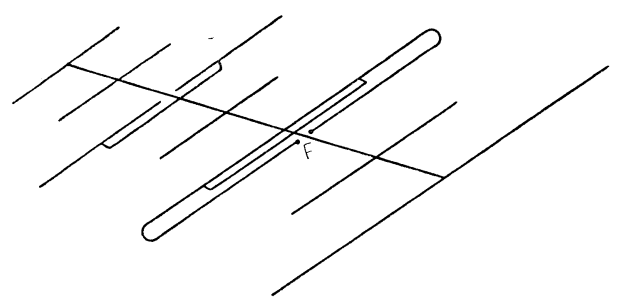

第 10 図 複合八木アンテナの一例

反射板
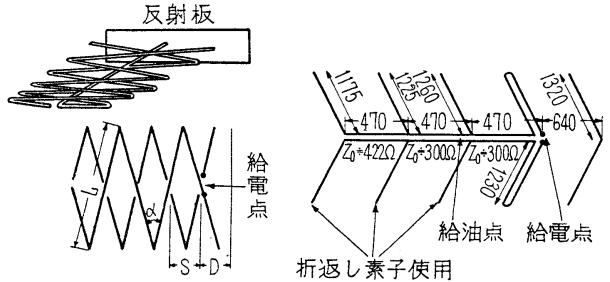

第 11 図 Series

第 12 図 Channel

Phombic Antenna
Master 製アンテナ 
高域 $5 \mathrm{~dB}$ 程度で全域 SWR 2.0 以内である.

（3）受信用伝送系 ${ }^{(19)(20)}$

受信用伝送系としては減衰器, 分配回路, 変成器, チ ヤネル合成用分波器, チャネル除去用回路などが要求さ れ, 小型, 安価で特性が全チャネルにわたって良好なる のが研究された. これらの小型伝送機器の使用によって 画質の向上が試みられつつある.さらに広帯域な移相器 の開発も要望されているが，現在のところまだ完成され ていない.

テレビジョン共同受信装置よりの漏洩電波について， 電波技術審議会第 3 部会第 1 小委員会で調査検討を行い その取締り規則の必要を認めて扣り， G 線路执よび同軸 ケーブルの接続コンネッター, 增幅器, その他より漏洩 が相当生じ, 設備より $3 \mathrm{~m}$ 以内で $30 \sim 40 \mathrm{~dB} / \mathrm{m}$ の漏洩 があることが知られ，今後これが対策が要望されている。

\section{むすび}

テレビ用アンテナは送信受信系をとわず，チャネルの 増加と画質改善のために幾多の努力が払らわれ, ここ数 年にして著しい向上がみられている. しかしテレビ送信 アンテナでは将来に拈ける FM 放送, UHF テレビ放送 カラー・テレビ放送などに対し，より良いアンテナの開 発に向いていき，種々の研究調査の成果を期待されてい る. また受信アンテナについても広帯域, 高利得空中線 の出現とゴーストなどの妨害電波の除去に対する対策な らびに各種伝送機器の開発, 研究が要望されている.さ らに難視地区対策としての共同受信方式の開発，漏洩電 磁界の減少なぞ多くの問題も生じた. 今後これらの問題 の解決によって，来るべき年には現在より良い画質のテ レビを観賞し得ることとなろう。

\section{[参 考 文 献]}

（1） 竹内, 遠藤：東京タワーのテレビ放送アンテナについて，アンテ 于研究専門委員会資料 昭和 34 年 8 月号

（2）竹内, 吉崎, 松下, 湯川：太いポールのスーパー・ターンスタイ ルアンテナの水平指向性, 通信学会全国大会, 昭和 34 年 10 月

（3）传藤, 高木, 高橋: スーパー・ターンスタイル空中線の NS 面, $\mathrm{EW}$ 面の結合による定在波此の変化, テレビジョン,昭和 34 年 8 月号

（4）内田, 佐藤, 永井 : テレビショョン放送空中線系の SWR 特性に 関する一問題点について, アンテナ研究専門委員会資料, 昭和 34 年 8 月号

（5）佐藤(源)，大場：パットウイング空中線素子間の結合量の测定， アンテナ研究專門委員会資料 昭和 35 年 1 月号

（6）松下:スーパー, ゲーンアンテナの水平指向性, アンテナ研究専 阴委員会資料, 昭和 35 年 3 月号

（7）佐藤, 永井：非対称がイポール空中線, アンテナ研究專門委員会 資料, 昭和 35 年 1 月号

(8) RCA Television Technical Manual: UHF Pylon Antennas.

(9) Alford Manufacturing Co: Antenna Systems Components Air Navigation, Aids Instruments. 1956

(10) L. O. Krause: Side-fire helix UHF-TV Transmitting Antenna, Electronics Ang. 1951

（11）遠藤, 清水, 竹脇, 近藤, 堂迫: サイドファイヤー, ヘリカルア ンテナの実験研究, NHK 技術研究, 昭和 32 年 3 月

(12) Merrell, McKean, Arbuthnott, Jr.-Styroflex AirDielectric Cable, AIEE Jan, 1957

（13）遠藤：FM 放送用高調波乃波器の一設計法（その一） NHK 技 術研究, 昭和 32 年 12 月号

(14) V.H. Rumsey, "Frequency independent antenna", I. R.E. National Convention Record Part 1, 1957

（15）森田, 高橋: 対数周期アンテナの特性について, アンテナ研究專 門委員会資料，昭和 34 年 12 月号

(16) R.H.Du Hamel, F. R.Ore"'Logarithmically periodic antenna designs', IRE National convention Record Part 1, 1958

（17）内田，佐藤，永井：TV 受信用広带域空中線，テレビジョン，昭 和 34 年. 5 月号

(18) W. A. Cumming: "A Nonresonant Endfire Array for VHF and UHF", IRE Trans. Ant and prop vol. AP-3 No. 2

（19）佐藤：テレビジョン共同受信について，アンテナ研究専門委員会 資料 昭和 34 年 8 月

（20）永井，佐藤，千葉： $\mathrm{G}$ 線路，ら線型線路上りの浑洩電磁界の測定 電波技術賽議会 第三部会第一小委員会資料

UDC 621.397.62(058)

\section{6. 受 像 機}

日本ビクター(株)黑岩寛

の初期に㧊いては，テーブル型受像機はスピーカをキャ ビネットの側面または上面に取付けたものが大部分であ ったが, 正面から音が出る方が自然な感じを受けるので, スピーカを正面に置いたものが段々多くなり，また音質 をよくするためスピーカを二個以上つけたものも現われ

(261) 17 